\title{
Social Management: Possibilities and Challenges of a Brazilian Concept
}

\author{
Airton Cardoso Cançado* \\ Federal University of Tocantins, Brazil \\ Submission: July 17, 2018; Published: July 31, 2019 \\ *Corresponding author: Airton Cardoso Cançado, Federal University of Tocantins, Brazil
}

\section{Opinion}

Social Management is a field of studies that has been developing in Brazil since the 1990s. Its theoretical and practical development combines with the return of democracy in the country and the new constitution of 1998.

Social Management presented here is a Brazilian construct in essence. Recent research has not found similarities with the construct in Spanish [1] and English [2]. However, with the publication of some texts with the discussion of the theme in recent international congresses, such as the ISTR - International Society for Third Sector Research [3-5] and this text, the invitation is for the discussion to be broadened internationally. Social management can be defined as collective decision-making without coercion. Decision-making should also have other characteristics: transparency, dialogue and intersubjectivity. There is a theoretical approach, already in its third version [6], that presents theoretical categories for the understanding of the construct, as shown in Figure 1.

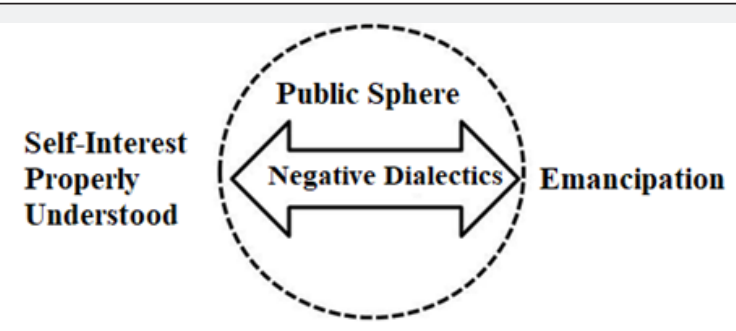

Figure 1: Theoretical approach for Social Management [6].

By this theoretical approximation, there are three major categories and a dynamics of relationship between them. The Self-interest Properly Understood (SIPU) refers to the balance between individual and collective interest [7]. What is perceived today is a polarization between an aggressive individual interest and a struggle for collective interest over individual interest. The proposal here is balance. Emancipation, as a theoretical category in this context refers to "thinking for oneself" and getting rid of someone's guardianship [8]. In short, be the owner of your own destiny and decisions. It is understood that we live in society and it is clear that the social conditions have influence in some types of action, but, what it understands here by Emancipation, is that one perceives, in a clear and conscious way this context. The Public Sphere is the space for collective decision-making, it is the rapprochement of management with politics. It is the space where individuals relate (SIPU and Emanciapação) in a negative dialectic way [9]. The negative dialectic of Adorno (Frankfurt) is the dynamics of relationship in this theoretical approach.

The negative dialectic is formed by thesis / antithesis without synthesis, or, without false syntheses [9].

All these theoretical categories are ideal Weberian types, that is, they are a place where one wants to arrive. Where the path is more important than the arrival. In summary, the theoretical approach shows that by increasing one side (SIPU or Emancipation) there is a direct influence on the other side, since there is no synthesis. Social Management is perceived as a process under construction and not a given reality. It can not be said that there is or is not social management in a organization or decision-making process. It can be said that Social Management is more or less presente [6].

The research agenda of the area foresees the advancement of this theoretical approach, concomitantly with the search for methodologies to foster this process. The great challenge nowadays is to combine direct (not representation) collective decision-making with Information and Communication Technologies - ICTs. Especially in large spaces such as Brazil [6]. One of the spaces for the construction of Social Management is the Network of Researchers in Social Management - RGS and its biennial event, the National Meeting of Researchers in Social Management, whose 11th Edition takes place in May 2020 in Maceió / AL, Brazil. Now, more than before, Social Management presents itself as a possibility for the development of society. The rise of the right wing in several countries makes this discussion even more necessary. 


\section{References}

1. Hernandéz AR, Cançado AC (2017) Analisis de gestión socialbrasileña a través de la teoría de la decolonialidad, AOS 6(1): 25-43.

2. Cançado AC. Marinho FA. Iwamoto HM (2018) Social Management: An Anglophone Perspective in International Conference on Democratic Governance in Developing World, 4, 2018, Rio de Janeiro, Anais..., Rio de Janeiro: EBAPE/FGV.

3. Vasconcellos Sobrinho M, Cançado AC, Vasconcellos AMA, Rigo AS (2016) Common Resources Management and Social Management theoretical and conceptual distinctions and approaches in ISTR's $12^{\text {th }}$ International Conference: The Third Sector in Transition: Accountability, Transparency, and Social Inclusion, 12, Stockholm, Anais..., 2016 Stockholm: ISTR pp. 1-15.

4. Cançado AC, Pozzebon M (2016) Social management: the potentia contribution of a Brazilian research tradition to the international nonprofit debate in ISTR's $12^{\text {th }}$ International Conference: The Third Sector in Transition: Accountability, Transparency, and Social Inclusion, 12, Stockholm, Anais..., Stockholm: ISTR, pp.1-15.

5. Marinho FA, Cançado AC (2018) Icelandic Crowdsourced Constitution and Social Management: Practice and Theory in Citizens Democratic Participation in International Conference of the International Society for Third-Sector Research (ISTR), 13, 2018, Amsterdam. Annals..., Amsterdam: ISTR.

6. Cançado AC, Pereira JR, Tenório FG (2015) Gestão Social: epistemologia de um paradigma, ( $\left.2^{\text {nd }} e d n\right), C R V$, Curitiba.

7. Tocqueville A (1987) Democracia na América. Traduzido e notas Neil Ribeiro da Silva, (2 ${ }^{\text {nd }}$ edn), Belo Horizonte: EDUSP; Itatiaia.

8. Chaui M (2011) Cultura e democracia: o discurso competente e outras falas, (13 ${ }^{\text {th }}$ edn), Cortez, São Paulo, Brazil, pp. 368.

9. Adorno TW (2009) Dialética negativa, Tradução: Marco Antonio Casanova; revisão técnica: Eduardo Soares Neves Silva. Rio de Jorge Zahar Janeiro, Brazil, p. 352.

\section{Your next submission with Juniper Publishers will reach you the below assets}

- Quality Editorial service

- Swift Peer Review

- Reprints availability

- E-prints Service

- Manuscript Podcast for convenient understanding

- Global attainment for your research

- Manuscript accessibility in different formats

( Pdf, E-pub, Full Text, Audio)

- Unceasing customer service

Track the below URL for one-step submission https://juniperpublishers.com/online-submission.php 